\title{
PENGARUH METODE PEMBELAJARAN KOOPERATIF TERHADAP HASIL BELAJAR MATEMATIKA (Studi Eksperimen pada Siswa Kelas XI SMK Bina Insan Kamil Bekasi)
}

\author{
SITI JULAEHA \\ Program Studi Teknik Informatika, Universitas Indraprasta PGRI \\ email: nyooi.sholeha@gmail.com
}

\begin{abstract}
The purpose of this study was to determine differences in the use of methods of cooperative towards mathematics learning outcomes. The research method used was experimental, with a sample of each group of 20 people, who were taken using purposive random sampling technique. The instrument used is a multiple choice test instrument as many as 20 questions. Test requirements on the data analysis is using test Liliefors normality test and homogeneity test using the F test (Fisher), and the results were normal distribution of data as well as meet the test of homogeneity of the data that is homogeneous, so it can proceed with a comparative analysis of non-parametric statistics. Hypothesis test results showed that the value $t_{\text {acount }}=6.83506$ and $t_{\text {tabel }}$ value for $\alpha=0.05$ and $d f=38$ by 2.02; which means there are significant cooperative learning methods on learning outcomes in mathematics. For further recommended that teachers strive to prepare cooperative learning methods, so that the process of learning mathematics can be both effective and efficient.
\end{abstract}

Keywords: methods, learning outcomes, mathematics

\section{PENDAHULUAN}

Untuk mewujudkan pendidikan yang berhasil dan berstandar nasional dan menjadikan siswa semangat untuk belajar, maka perlu seorang pendidik yang propesional diantaranya yaitu selain untuk mencapai metode sendiri di dalam cara mengajar maupun cara belajar siswa. Kenyataan yang kita hadapi selama ini banyak kita jumpai pengajar yang mengembangkan metode pembelajaran yang tidak sesuai dengan apa yang diinginkan siswa. Oleh karena itu guru memiliki peranan penting dalam perkembangan pendidikan siswa karena sebagian besar waktu siswa mereka habiskan di sekolah. Namun sangat disayangkan pembelajaran yang berjalan pada saat ini tidak mengarah pada bagaimana cara siswa dapat mengembangkan pendidikkannya. Tetapi pembelajaran hanya mengarah pada bagaimana siswa dapat memenuhi standar kompetensi yang telah ditetapkan. Sehingga dalam proses pendidikan guru hanya memberikan materi saja sedangkan siswa harus mencari tahu sendiri pemecahan masalah latihan-latihan soal yang diberikan tanpa adanya komunikasi yang baik antara guru dan siswa.

Pembelajaran di atas dapat kita lihat dalam cara pengajaran guru sehari-hari saat kegiatan belajar mengajar sedang berlangsung. Kebanyakan dari guru-guru yang mengajar di kelas menggunakan metode pembelajaran yang tidak sesuai dengan keadaan 
dan kondisi kelas. Namun pada kenyataannya tidak semua siswa dapat menangkap atau menerima materi yang disampaikan secara optimal dengan strategi pembelajaran yang tidak sesuai tersebut. Hal ini disebabkan perbedaan kemampuan siswa dalam mendengar dan memaknai penjelasan dari gurunya. Jadi sulit rasanya untuk membuat siswa untuk memahami materi yang disampaikan oleh guru. Terlebih lagi pada mata pelajaran matematika yang memerlukan penjelasan yang sangat mendetail. Apabila siswa tidak dapat memahami dan menerima materi dengan baik, maka akan sangat mempengaruhi hasil belajar siswa khususnya pada bidang Matematika.

Melihat hal tersebut diperlukan suatu metode atau strategi pembelajaran yang baru yang dapat dengan mudah dilakukan dan diterapkan kepada siswa. Salah satu metode yang menurut penulis sangat baik dan mudah diterapkan adalah metode "Pembelajaran Kooperatif". Adapun metode "Pembelajaran Kooperatif" merupakan sebuah kelompok strategi pengajaran yang melibatkan siswa bekerja secara berkolaborasi untuk mencapai tujuan bersama. "Pembelajaran Kooperatif" biasanya menempatkan siswa dalam kelompok-kelompok kecil selama beberapa minggu atau bulan ke depan. Dengan metode ini akan menambah keberanian siswa dalam mengungkapkan pendapat, belajar sosialisasi, menambah kepercayaan kemampuan berpikir sendiri, dan siswa dapat belajar dengan siswa yang lainnya.

Dengan metode ini diharapkan dapat digunakan untuk meningkatkan hasil belajar matematika adalah karena metode ini mengasah kemampuan siswa dalam bersosialisasi dengan temannya, dapat mengembangkan kemampuan mengungkapkan ide atau gagasan dengan kata-kata secara verbal, membantu siswa untuk menghormati orang lain dan menyadari akan segala keterbatasan dan menerima segala perbedaan.

\section{TINJAUAN PUSTAKA}

\section{Belajar}

Belajar adalah usaha untuk mengubah perilaku, melalui aktivitas, interaksi atau kegiatan yang dapat menambah, mengubah mengembangkan pengetahuan, keterampilan dan sikap. Berdasarkan pendapat Wina Sanjaya (2009:229), Belajar pada dasarnya adalah suatu proses aktivitas mental seseorang dalam berinteraksi dengan lingkungannya sehingga menghasilkan perubahan tingkah laku yang bersifat positif baik perubahan dalam aspek pengetahuan, sikap, maupun psikomotorik. 


\section{Hasil Belajar}

Hasil belajar adalah penampilan dan tingkah laku yang diperoleh siswa dari hasil pengorganisasian aktivitas pendidikan, yang sengaja dan berkesinambungan sehingga muncul sikap yang lebih baik dari proses belajar yang dilakukan oleh siswa. Berdasarkan Gagne dikutip Hamzah B.Uno (2010:137), hasil belajar adalah kapasitas terukur dari perubahan individu yang diinginkan berdasarkan ciri-ciri atau variabel bawaannya melalui perilaku pengajaran tertentu. Dengan demikian hasil belajar adalah hasil dari suatu proses belajar mengajar yang dapat diukur dari perubahan siswa, apakah siswa tersebut telah menguasai tujuan pengajaran yang diinginkan.

\section{Matematika}

Menurut Suriasumantri (2007:190), matematika adalah yang melambangkan serangkaiaan makna dari pernyataan yang ingin disampaikan. Lambang-lambang ini bersifat artifisial (buatan) yang baru mempunya arti setelah diberi makna. Tanpa ini semua, rumus-rumus ini sangat sulit untuk dipahami, untuk memahami sebuah simbol harus diberi makna. Dengan demikian matematika memiliki serangkaian lambanglambang dan simbol-simbol yang diberi makna terlebih dahulu agar mempunnyai arti yang dapat dipahami, matematika memiliki keunikan tersendiri dalam fungsinya sebagai lambang yang dipakai dalam komunikasi ilmu pengetahuan.

\section{Hasil Belajar Matematika}

Hasil belajar matematika dapat dilihat dari nilai yang diperoleh siswa sebagai hasil dari proses belajar matematika. Selain itu hasil belajar matematika juga dapat dikatakan sebagai suatu kondisi perubahan tingkah laku setelah siswa mengalami proses pelajaran matematika. Menurut Taksonomi Bloom seperti yang dikutip oleh Hasanah, Perubahan tingkah laku seseorang tingkah laku seseorang sebagai hasil belajar dapat diklasifikasikan menjadi: 1) Kognitif yaitu berkaitan dengan aspek pengetahuan dan kemampuan intelektual seseorang. Hasil dari aspek kognitif adalah kemampuan mengingat, memahami, menganalisa, menghubungkan dan memecahkan masalah. 2) Afektif yaitu berkaitan dengan perasaan nada emosi dan variabel tingkat penerimaan dan penolakan terhadap sesuatu. 3) Psikomotorik yaitu berkaitan dengan gerakan otot, misalnya aktivitas tulis-menulis, kemampuan menggambar bidang, dan menyusun percobaan matematika. 


\section{Metode Pembelajaran}

Menurut syah (2010:201), Metode Pembelajaran adalah cara yang berisi prosedur baku untuk melaksanakan kegiatan pendidikan khususnya kegiatan penyajian materi kepada siswa. Guru dalam menerapkan metode-metode pembelajaran terlebih dahulumelihat situasi dan kondisi yang paling tepat untuk menerapkannya suatu metode tertentu agar dalam situasi dan kondisi untuk membawa siswa kearah yang sesuai dengan tujuan matei yang diajarkan. Dengan demikian metode pembelajaran adalah suatu usaha atau cara yang dilakukan guru dalam menyampaikan menerima dan menanggapi serta mencerna pelajaran dengan mudah secara efektif dan efisien sehingga apa yang menjadi tujuan dari pembelajaran tersebut dapat tercapai.

\section{Pembelajaran Kooperatif}

Menurut pendapat Roger yang dikutip oleh Huda (2011:29) yaitu Pembelajaran kooperatif merupakan aktivitas pembelajaran kelompok yang diorganisasikan oleh satu prinsip bahwa pembelajaran harus didasarkan pada perubahan informasi secara sosial diantara kelompok-kelompok pembelajaran yang di dalamnya setiap pembelajaran bertanggung jawab atas pembelajaran sendiri didorong untuk meningkatkan pembelajaran anggota-anggota yang lain.

Adapun unsur-unsur penting dalam metode pembelajaran kooperatif, yaitu:

a. adanya peserta dalam kelompok;

b. adanya aturan dalam kelompok;

c. adanya upaya belajar setiap anggota kelompok;

d. adanya tujuan yang harus dicapai.

Keunggulan pembelajaran kooperatif sebagai suatu metode pembelajaran di antaranya

a. Siswa tidak terlalu bergantung pada guru, akan tetapi dapat menambah kepercayaan kemampuan berpikir sendiri, menentukan informasi dari berbagai sumber, dan belajar dari siswa yang lain.

b. Siswa untuk dapat lebih mengembangkan kemampuan mengungkapakan ide atau gagasan dengan kata-kata secara verbal dan membandingkannya dengan ide-ide orang lain.

c. Membuat anak memiliki sifat respek pada orang lain dan menyadari akan segala keterbatasannya serta menerima akan segala perbedaan. 
d. Setiap siswa memiliki rasa tanggung jawab yang lebih dalam belajar.

e. Metode ini dapat meningkatkan prestasi akademik sekaligus kemampuan sosial siswa, termasuk pengembangan rasa harga diri, hubungan interpersoal yang positif dengan yang lain, mengembangkan keterapilan me-manage waktu, dan sikap positif terhadap sekolah.

Kelemahan pembelajaran kooperatif sebagai metode pembelajaran diantaranya:

a. Untuk memahami dan mengerti filosofis pembelajaran kooperatif ini memang butuh waktu. Untuk siswa yang dianggap memiliki kelebihan, contohnya mereka akan meras terhambat oleh siswa yang dianggap kurang memiliki kemampuan. Akibatnya, keadaan semacam ini dapat mengganggu iklim kerja sama dalam kelompok.

b. Ciri utama dari pembelajaran kooperatif adalalah siswa saling membelajarkan. Oleh karena itu, jika tanpa peer teaching yang efektif, maka dibandingkan dengan pengajaran langsung dari guru, bisa jadi belajar yang demikian apa yang seharusnya dipelajari dan dipahami tidak pernah dicapai siswa.

c. Penilaian yag diberikan dalam pembelajaran kooperatif didasarkan kepada hasil kelompok. Namun demikian, pendidik perlu menyadari, bahwa sebenarnya hasil atau prestasi yang diharapkan adalah prestasi setiap individu siswa.

Menurut Eggen dan Kauchak yang dikutip oleh Trianto (2007:42), Tujuan kooperatif merupakan sebuah strategi pengajaran yang melibatkan siswa bekerja sama. Pembelajaran kooperatif disusun dalam sebuah usaha untuk meningkatkan partisipasi siswa, memfasilitasi siswa dengan pengalaman sikap kepemimpinan dan membuat keputusan dalam kelompok, serta memberikan kesempatan pada siswa untuk berinteraksi dan belajar bersama-sama siswa yang berbeda latar belakangnya.

\section{Pembelajaran Kooperatif tipe Jigsaw}

Metode pembelajaran kooperatif tipe Jigsaw merupakan metode kelompok yang terdiri dari kelompok ahli karena setiap anggota dihadapi permasalahan yang berbedabeda. Namun permasalahan yang dihadapi setiap anggota kelompok itu sama dan disebut kelompok team ahli yang bertugas membahas permasalahan yang dihadapi. Selanjutnya hasil pembahsan itu dibawa ke kelompok asal dan disampaikan pada anggota kelompoknya. Dengan metode ini siswa dapat berdiskusi mengenai materi yang mereka dapat masing-masing sehingga siswa belajar berani mengungkapkan pendapatnya dan keterampilan bekerja. 
Adapun langkah-langkahnya yaitu:

a. Pengajar membagi bahan pelajaran yang akan diberikan menjadi empat bagian

b. Sebelum bahan pelajaran diberikan pengajar memberikan pengenalan mengenai topik yang akan dibahas dalam pelajaran hari itu. Pengajar bisa menulis topik di papan tulis dan menanyakan apa yang siswa ketahui tentang topik tersebut. Kegiatan brainstorming ini dimaksudkan untuk mengaktifkan skemata siswa agar lebih siap untuk menghadapi bahan pelajaran yang baru

c. Siswa dibagi dalam kelompok berempat

d. Bagian pertama bahan diberikan kepada siswa pertama, sedangkan siswa yang kedua menerima bahan yang kedua. Demikian seterusnya

e. Kemudian siswa disuruh membaca atau mengerjakan bagian mereka masing-masing

f. Setelah selesai, siswa saling berbagi mengenai bagian yang dikerjakan masing-masing

g. Kegiatan ini bisa diakhiri dengan diskusi mengenai topik dalam bahan pelajaran hari itu.

\section{Metode Pembelajaran Kooperatif tipe Numbered Heads Together}

Metode pembelajaran kooperatif tipe NHT merupakan metode yang menekankan pda struktur-struktur khusus yang dirancang untuk mempengaruhi pola-pola interaksi siswa dan memiliki tujuan untuk meningkatkan penguasaan akademik sehingga meciptakan siswa-siswi yang aktif, meningkatkan kepekaan diri dengan temannya, dan menjadi siswa yang berani mengungkapkan pendapatnya.

Adapun ada enam langkah metode pembelajaran kooperatif NHT sebagai berikut:

a. Siswa dibagi dalam kelompok, setiap siswa dalam setiap kelompok mendapat nomor.

b. Guru memberikan tugas dan masing-masing kelompok mengerjakannya.

c. Kelompok mendiskusikan jawaban yang benar dan memastikan tiap anggota kelompok dapat mengerjakannya.

d. Guru memanggil salah satu nomor siswa dengan nomor yang dipanggil melaporkan hasil kerjasama mereka.

e. Tanggapan dari teman yang lain, kemudian guru menunjuk nomor yang lain.

\section{METODE}

Dalam Arikunto (2010:237) eksperimen atau komparatif yaitu metode penelitian yang bertujuan untuk melakukan percobaan dengan membandingkan dua atau tiga dengan 
melihat penyebab-penyebabnya. Dengan demikian Penelitian ini menggunakan Metode eksperimen komparatif bertujuan untuk melakukan percobaaan dengan membandingkan dua kejadian untuk menemukan persamaan dan perbedaan terhadap masalah yang dibahas oleh peneliti. Dimana pada penelitian eksperimen, peneliti melakukan manipulasi kondisi dengan memberikan perlakuan atau menciptakan sebuah kondisi dengan memberikan perlakuan atau menciptakan sebuah kondisi atau rangsangan pada subjek yang ditelitinya.

Hasil belajar matematika siswa sebagai data dalam penelitian ini, dikelompokan menjadi dua kelompok yaitu hasil belajar matematika siswa kelompok kelas eksperimen dan hasil belajar matematika siswa kelompok kelas kontrol. Hasil belajar matematika tersebut diambil dari hasil tes materi pelajaran yang digunakan untuk eksperimen.

\section{Desain Penelitian}

Berikut adalah gambaran desain penelitian yang digunakan :

\begin{tabular}{|lll|}
\hline $\mathrm{E}: \mathrm{X}_{1}$ & $\longrightarrow \mathrm{O}_{1}$ \\
\hline $\mathrm{K}: \mathrm{X}_{2}$ & $\longrightarrow \mathrm{O}_{2}$ \\
\hline
\end{tabular}

\section{Gambar 1. Desain Penelitian}

Keterangan:

$\mathrm{X}_{1}$ : Kelompok kelas eksperimen (Pembelajaran Kooperatif tipe Jigsaw)

$\mathrm{X}_{2}$ : Kelompok kelas kontrol (Pembelajaran Kooperatif tipe Numbered Heads

Together/NHT)

$\mathrm{O}_{1}$ : Hasil belajar matematika kelas eksperimen

$\mathrm{O}_{2}$ : Hasil belajar matematika kelas control

\section{HASIL DAN PEMBAHASAN}

Hasil perhitungan yang menyatakan bahwa $\mathrm{L}_{\text {hitung }}<\mathrm{L}_{\text {tabel }}$ atau $(0,1033<0,190)$ maka terima $\mathrm{H}_{0}$ dan tolak $\mathrm{H}_{1}$. Sehingga dapat disimpulkan bahwa data untuk kelas eksperimen berasal dari populasi berdistribusi normal dan hasil perhitungan yang menyatakan bahwa $\mathrm{L}_{\text {hitung }}<\mathrm{L}_{\text {tabel }}$ atau $(0,1119<0,190)$ maka terima $\mathrm{H}_{0}$ dan tolak $\mathrm{H}_{1}$. Sehingga dapat disimpulkan bahwa data untuk kelas kontrol berasal dari populasi berdistribusi normal. Hasil analisis homogenitas dengan nilai $\alpha=0,05$ diperoleh bahwa harga $F_{\text {hitung }}<F_{\text {tabel }}$ atau $(1<2,16)$.Sehingga disimpulkan bahwa data penelitian tersebut memiliki varians yang homogen. Hasil uji coba Metode Pembelajaran Kooperatif yang 
peneliti lakukan memeperoleh hasil rata-rata 72,6 pada tipe Jigsaw dan 52,6 pada tipe NHT, dan memiliki nilai $\mathrm{t}_{\text {hitung }}=6,8350$ dan nilai $\mathrm{t}_{\text {tabel }}$ untuk $\alpha=0,05 \mathrm{dan} \mathrm{dk}=38$ sebesar 1,684; yang berarti Metode Pembelajaran Kooperatif ini sangat berguna jika digunakan dalam pengajaran matematika dan sangat berpengaruh terhadap hasil belajar matematika siswa terutama di SMK Bina Insan Kamil Bekasi.

\section{SIMPULAN}

Berdasarkan data, analisis deskripsi dan pengolahan data statistik maka dapat diambil kesimpulan sebagai berikut :

Hasil perhitungan Uji Liliefors menyimpulkan galat taksiran regresi berdistribusi normal untuk data kelas eksperimen dan data kelas untuk kontrol. Untuk hasil perhitungan ukuran pemusatan data, letak dan keragaman siswa yang diajarkan dengan Metode pembelajaran kooperatif tipe Jigsaw bernilai baik, sedangkan metode pembelajaran yang menggunakan tipe NHT berada pada kategori cukup baik.

Hasil uji coba Metode Pembelajaran Kooperatif yang peneliti lakukan memeperoleh hasil rata-rata 72,6 pada tipe Jigsaw dan 52,6 pada tipe NHT, dan memiliki nilai $\mathrm{t}_{\text {hitung }}=6,8350$ dan nilai tabel untuk $\alpha=0,05 \mathrm{dan} \mathrm{dk}=38$ sebesar 1,684; yang berarti Metode Pembelajaran Kooperatif ini sangat berguna jika digunakan dalam pengajaran matematika dan sangat berpengaruh terhadap hasil belajar matematika siswa terutama di SMK Bina Insan Kamil Bekasi.

\section{SARAN}

Berdasarkan hasil penelitian beberapa saran yang dapat dikemukakan sebagai bahan masukan yang bermanfaat untuk sekolah adalah sebagai berikut:

1. Sebagai calon pengajar atau pendidik sebaiknya membantu siswa untuk lebih mengenal tentang metode pembelajaran kooperatif sehingga memberikan peluang yang besar bagi siswa untuk memperoleh hasil belajar yang terbaik.

2. Sekolah berupaya meningkatkan kompetensi guru dalam rangka mempersiapkan bahan ajar dan juga penggunaan metode belajar, baik metode pembelajaran kooperatif.

3. Hasil penelitian ini memberikan Pengaruh Metode Pembelajaran Kooperatif terhadap hasil belajar matematika siswa. Dengan siswa yang diajar menggunakan tipe Jigsaw dan siswa yang diajar menggunakan tipe NHT. Sehingga untuk selanjutnya, guru dapat 
Research and Development Journal of Education

Vol. 3 No.1 Oktober 2016

ISSN 2406-9744

berupaya untuk selalu menggunakan metode pembelajaran kooperatif dalam menjelaskan berbagai materi matematika khususnya materi barisan dan deret.

\section{DAFTAR PUSTAKA}

Arikunto, Suharsimi.2010.Cet.1. Strategi Pembelajaran Sekolah Terpadu. Jakarta. Prestasi Pustaka.

Huda, Miftahul. 2011 .Cet.1. Cooperatif Learning. Pustaka Pelajar. Yogyakarta.

Sanjaya, Wina. 2009. Kurikulum dan Pembelajaran. Kencana Prenada Media Group. Jakarta.

Suriasumantri, Jujun S. 2007. Filsafat Ilmu Sebuah Pengantar Populer. Jakarta. Sinar Harapan.

Syah, Muhibbin. 2010. Cet.15. Psikologi Pendidikan dengan Pendekatan Baru. Bandung.Remaja Rosdakarya.

Trianto.2007.Cet.1. Model-Model Pembelajaran Inovasi Berorientasi Konstruktivistik. Jakarta. Prestasi Pustaka Publisher.

Uno, Hamzah B dan Nina Lamatenggo. 2010. Teknologi Komunikasi dan Informasi Pembelajaran. Bumi Aksara. Jakarta. 